\title{
In Memoriam: John Henry Holland-a pioneer of complex adaptive systems research (February 2, 1929-August 9, 2015)
}

\author{
Muaz A. Niazi i (D)
}

*Correspondence:

muaz.niazi@gmail.com;

muaz.niazi@ieee.org

Department of Computer

Science, COMSATS Institute

of IT, Islamabad, Pakistan
"The study of cas is a difficult, exciting task. The returns are likely to be proportionate to the difficulty." Holland (2006)

On August 9, 2015, cancer took Prof. John Henry Holland away from us. Prof. Holland was a pioneer of Complex Adaptive Systems (CAS) research and a true inspiration. He is known not only for his work on CAS, Holland $(1962,1992)$ - which he would fondly write as "cas" - but also for his seminal work on adaptation in natural and artificial systems leading to the creation of genetic algorithms and eventually the fields of evolutionary computation, Holland (1995) and Learning Classifier Systems, Holland and Holyoak (1989).

Holland was a truly interdisciplinary academic. He had an undergraduate degree in Physics from MIT (1950), an M.A. in Mathematics (1954) and possibly the first ever PhD in Computer Science (1959), both from the University of Michigan-a place where he also subsequently served as a Professor of Psychology, Electrical Engineering and Computer Science.

Holland leaves behind his legacy in the form of a large number of thought-provoking articles, video lectures, books, and inspired people-ranging from colleagues, fellows and students to budding complexity enthusiasts. Two of his recent books summarize his views on CAS in both a longer, Holland (2012) as well as a shorter form, Holland (2014). It is easy to foresee that these works will serve not only as a guide to CAS but also guidance for future generations. Holland will indeed be greatly missed.

Links to some of his online obituaries are as follows:

Melanie Mitchell http://tinyurl.com/qcj22tv

National Center for Science Education http://tinyurl.com/pm7ga8y

New York Times http://tinyurl.com/p5cd22u

Santa Fe Institute http://tinyurl.com/qhkgtxd

The Scientist http://tinyurl.com/pns6t64

University of Michigan http://tinyurl.com/obbdpx5

Washington Post http://tinyurl.com/oalp27x

Received: 30 October 2015 Accepted: 6 November 2015

Published online: 19 November 2015

() 2015 Niazi. This article is distributed under the terms of the Creative Commons Attribution 4.0 International License (http:// creativecommons.org/licenses/by/4.0/), which permits unrestricted use, distribution, and reproduction in any medium, provided you give appropriate credit to the original author(s) and the source, provide a link to the Creative Commons license, and indicate if changes were made. 


\section{References}

Holland JH (2006) Studying complex adaptive systems. J Syst Sci Complex 19(1):1-8

Holland JH (1962) Outline for a logical theory of adaptive systems. J ACM 9(3):297-314

Holland JH (1992) Complex adaptive systems. Daedalus 121(1):17-30. http://www.jstor.org/stable/20025416

Holland JH (1995) Hidden order: How adaptation builds complexity. Basic Books

Holland JH, Holyoak KJ (1989) Induction: Processes of inference, learning, and discovery. Mit Press

Holland JH (2012) Signals and boundaries: building blocks for complex adaptive systems. Mit Press

Holland JH (2014) Complexity: a very short introduction. Oxford University Press

Submit your manuscript to a SpringerOpen ${ }^{\circ}$ journal and benefit from:

- Convenient online submission

- Rigorous peer review

- Immediate publication on acceptance

- Open access: articles freely available online

- High visibility within the field

- Retaining the copyright to your article

Submit your next manuscript at $\mathbf{s p r i n g e r o p e n . c o m ~}$ 